\title{
Effects of Allegations Regarding the Use of Antibiotics and Hormones in Diets on Consumer Perceptions, Attitudes and Behaviors towards Broiler Meat Consumption
}

\author{
Kerem Karasu ${ }^{1, a}$, Ergin Öztürk ${ }^{2, b, *}$ \\ ${ }^{1}$ Department of Animal Science, Institute of Sciences, Ondokuz Mayls University, 55139 Samsun, Turkey \\ ${ }^{2}$ Department of Animal Science, Faculty of Agriculture, Samsun Ondokuz Mayis University, 55270 Samsun, Turkey \\ *Corresponding author
}

A R T I C L I N F O A B S T R A T

Research Article

This research has been carried out to determine the effects of the current misinformation (hormone, antibiotic, feed additives and growth of broiler chickens in a short period) on consumers' view of the poultry meat sector. The survey was conducted in Istanbul province which better reflects the socio-cultural and socio-economic structure of Turkey, and with different demographic structure of

Received : 22/10/2020

Accepted : 23/11/2020

384 people face to face survey method was applied. Questions were asked to determine whether antibiotics and hormones were used in the diet of broiler chickens, and consumers' perceptions, attitudes and behaviors about the reliability of chicken meat. According to the results of the study, $73.4 \%$ of the consumers stated that they did not know about the contents of broiler diets. A big majority of the consumers $(88.3 \%$ ) stated that they think hormone is used and $84.6 \%$ think antibiotics is used in the feeding of broiler chickens. $78.4 \%$ of consumers surveyed stated that they

Keywords:

Broiler meat

Hormone

think that broiler chickens are not fed with healthy feed. Also, $70.6 \%$ of consumers stated that rapid

Antibiotic growth was due to use of antibiotics and hormones. Although the use of hormones and antibiotics

Safe food

Healthy nutrition as growth promoters in poultry feeds is prohibited, consumers think that they are used as additives and broiler meat is not safe food. According to these results, creating a positive effect on the purchasing decisions of the consumers is important for the sustainability and future of the sector.

\section{Introduction}

Broiler meat is one of the most important sources of animal protein, providing nutrients at a lower cost and for a healthy and balanced diet. Considering the forecast that world meat consumption will increase by $72 \%$ between 2000 and 2030 (Fiala, 2008), it has been suggested that global meat production will more than double between 2000 and 2050 due to increasing world population, urbanization and increased incomes (Steinfeld et al., 2006) . The poultry industry has an advantage because chickens have a higher feed conversion efficiency compared to other livestock, with less input and cost, and a higher yield per unit area (FAO, 2017; Öztürk, 2017; Öztürk et al., 2012). In addition, chicken meat has an important role in ensuring a sustainable food supply as it is a food with lower greenhouse gas emissions than other protein sources (Caro et al., 2017). In the past, fewer researchers have been interested in factors affecting meat consumption when compared with the researcher on consumer perceptions of quality of the meat. The perception of food quality is changing with each passing year and it has become more dynamic but also more complexes (Naspetti et al., 2015). However, scientific studies and public debate on the ethical and environmental aspects of meat production and consumption can influence consumer perspectives on meat (Mayfield et al., 2007; Dokuzlu, 2013; İnci et al., 2014; Bryant et al., 2019; Şengül and Zeybek, 2020). However, to date, there is little research examining how and to what extent consumer expectations for meat and meat production conditions affect changes in consumption (Vackier, 2004; Verbeke et al., 2005; Topçu et al., 2015; Şengül and Zeybek, 2020).

Although it has never been used in poultry in many countries, the use of hormones in diets was banned in the 1970s and antibiotic use in 2006 (FDA 2016). However, controversy continues regarding the use of feed additives in diets. Scientific researches on the extent to which feed additives used in animal feed can be transferred to chicken meat and their effects are closely monitored by consumers. In a study aimed at evaluating the attitudes of consumers towards food safety, the factors that most concern 
consumers are; genetically modified organisms (GMO), artificial food color substances, meat, milk and poultry hormone and antibiotic residues, pesticide residues and food additives have been reported (Bekar, 2013; Demir and Aydin, 2018; Yang, 2017; Karasu and Ozturk, 2020). It has been reported in the written and visual media that speculations on poultry meat are seriously frightening beyond the fact that consumers are directed to avoid consuming poultry meat (Karadavut ve Taşkın, 2014). In many studies, it was reported that the incompatible news about the used the antibiotics and hormones in the broiler diets had a negative effect on chicken meat consumption (Verbeke, 2005; Topçu et al., 2015). Indeed, antimicrobials and growth hormones used to stimulate growth in animals cause controversy over the safety of livestock products (Jeong et al., 2010). Therefore, in this study, firstly, it was tried to determine how the consumers will react if hormone and antibiotics are used in the diet of broiler chickens. Secondly, it is aimed to investigate the level of consciousness of the consumer about hormones and antibiotics and whether they can be used in feeding. In addition, the awareness of feed additives used in chicken meat production was questioned and the changes in consumers' purchasing and general consumption trends were investigated.

\section{Material and Methods}

\section{Questionnaire}

The survey asked a number of questions regarding the participants' subjective and objective knowledge about the composition of diets, and use of antibiotics and hormones. A quantitative questionnaire was developed to achieve the objectives of the study, and it was carried out face-to-face using the single-stage random sampling method in Istanbul between March and June 2017. All of the participants (384) were over the age of 18 , the number of participants (Collins, 1986) and the location of residence was predetermined. A questionnaire was prepared to measure consumers' demographic characteristics, general purchasing preferences and behaviors, and broiler feed and product quality perceptions. Firstly, the participants were asked five questions regarding their age, gender, and educational status, number of individuals in the family and income status. In the second group of questions, it was questioned whether the consumers knew basic feeding information such as how broiler chickens are fed, what the mixed feeds consist of, their level of knowledge about GMO, what feed additives are included in diets. In the third group of questions, the awareness of antibiotics for therapeutic purposes and antibiotics for growth, and their perceptions, attitudes and behaviors about the awareness that hormones and antibiotics for growth are prohibited. Finally, the awareness of consumers about chickens, which are used in production for a year and fed on a free-range system for one or two months, has been questioned. A total of 34 questions was asked in our survey study. However, in this article, 11 questions about hormone and antibiotics were evaluated together with 5 demographic structures. However, the answers given to the three questions below are given as a table and the changes occurred, according to the demographic structure are evaluated in more detail.
- Do you think hormones are used in the diet of broiler chickens?

- How does the use of therapeutic antibiotics in the feeding of broilers affect your purchasing decision?

- What do you think is the most important factor for broiler chickens to gain a live weight of $2.5-3.0 \mathrm{~kg}$ in a short time (42 days)?

In the thesis, eight questions about antibiotics and hormones were asked, but some of them were either graphically shown in this article or the results were briefly interpreted.

- Do you believe that feed additives are natural or harmless to human health?

- If you know that feed additives are harmless, how does this affect your chicken meat consumption?

- Do you think that the use of antibiotics to prevent infections in broiler chickens is harmful to human health?

- How will the use of antibiotics for therapeutic purposes only in the feeding of broiler chickens affect your purchase decision?

- How does the addition of natural additives such as plant extracts, essential oils, enzymes, probiotics into broiler diets affect your purchase and consumption amount?

- Do you have any information about which feed additives are included in the diets of broiler chickens?

- How do you think feed additives such as mold inhibitors, toxin binders, antioxidants, emulgators that can be found in the diets of broiler chickens affect human health?

- Do you think chicken meat sold on the market is safe? The questions in the questionnaire form were applied to the interviewers by the researchers themselves and explanatory information was provided when necessary. Data collection was carried out in one-to-one interviews with the participants on the grounds that there are many survey questions and that it will be better understood by explaining some of them. In this study, consumers' consumption trends were analyzed using the quartet and five-point Likert scale such as "does not affect at all", “" little affects","more affects" and "I buy more".

\section{Statistics}

Descriptive analysis and chi-square tests were used for the analysis of the data obtained from the survey. All statistical analyzes were performed in SPSS 21.0 program. Despite the fact that the number of pollsters is determined by statistical evaluation and is carried out with a limited number of pollsters, the results of this research can be reflected in the general population level, since face-to-face realization reflects the true feelings of the society.

\section{Results and Discussion}

\section{The Answers of Questionnaires to Demographic Structure}

Of the 384 consumers surveyed, $51.6 \%$ are between the ages of 18 and $45,34.1 \%$ are between the ages of 46 and 60 , and $14.3 \%$ are over the age of 60 . When education levels are analyzed, $66.9 \%$ of consumers are university graduates, $24 \%$ are secondary school and high school 
graduates, $8.3 \%$ are primary school graduates and $0.8 \%$ are literate. $7.3 \%$ of consumers surveyed are between $0-500$ USD, $26.3 \%$ between 500 - 1.000 USD, 40.4\% between 1.000 - 1.500 USD per month, $20.8 \%$ between 1.500 3.000 USD and $5.2 \%$ stated that they earned more than 3.000 USD. $86.7 \%$ of the respondents reported that they consumed broiler meat and $13.3 \%$ did not consume broiler meat.

\section{Responds of Questionnaires}

As explained in the method, 11 questions of the survey study are directly related to the awareness, perception, attitude and behavior regarding the use of antibiotics and hormones. Firstly, the following eight of these questions are shown graphically and/or the results obtained are briefly interpreted. Do you think that hormones are used in feeding the broiler chickens? Was asked to person serveyed (Table 1). A big majority of the consumers (88.3\%) stated that they think hormone is used in the feeding of broiler chickens and only $11.7 \%$ of them think that hormones are not used in production. In our study, $78.4 \%$ of consumers surveyed stated that they think that broiler chickens are not fed with healthy feed, while only $21.6 \%$ say they think they are fed with healthy feed. While $73.4 \%$ of the consumers stated that they did not know about the contents of broiler diets, 26.6\% stated that they had knowledge. The subject of using hormones in meat production attracts great attention from the media, consumers and other sources.

Table 1. Change of consumer opinion on whether or not to use hormones in broiler feeds by gender, age, number of family members, education and income $(\mathrm{N}=384)$

\begin{tabular}{|c|c|c|c|c|c|c|c|c|c|}
\hline & \multirow{2}{*}{$\mathrm{N}$} & \multicolumn{3}{|c|}{ Yes } & \multicolumn{3}{|c|}{ No } & \multirow[b]{2}{*}{$\chi^{2}$} & \multirow[b]{2}{*}{$\mathrm{P}$} \\
\hline & & $\mathrm{n}$ & $\%^{\mathrm{a}}$ & $\%^{\mathrm{b}}$ & $\mathrm{n}$ & $\%^{\mathrm{a}}$ & $\%^{\mathrm{b}}$ & & \\
\hline \multicolumn{10}{|c|}{ Gender } \\
\hline Male & 186 & 168 & 43.8 & 90 & 18 & 4.7 & 10 & \multirow{2}{*}{1.453} & \multirow{2}{*}{0.267} \\
\hline Female & 198 & 171 & 44.5 & 86 & 27 & 7 & 14 & & \\
\hline \multicolumn{10}{|c|}{ Age } \\
\hline $18-45$ & 198 & 175 & 45.6 & 88 & 23 & 6 & 12 & \multirow{3}{*}{0.065} & \multirow{3}{*}{0.968} \\
\hline $46-60$ & 131 & 116 & 30.2 & 89 & 15 & 3.9 & 11 & & \\
\hline $61>$ & 55 & 48 & 12.5 & 87 & 7 & 1.8 & 13 & & \\
\hline \multicolumn{10}{|c|}{ Family size } \\
\hline 2 & 45 & 45 & 11.7 & 100 & 0 & 0 & 0 & \multirow{5}{*}{21.100} & \multirow{5}{*}{$<0.001$} \\
\hline 3 & 48 & 45 & 11.7 & 94 & 3 & 0.8 & 6 & & \\
\hline 4 & 193 & 157 & 40.9 & 81 & 36 & 9.4 & 19 & & \\
\hline 5 & 65 & 59 & 15.4 & 91 & 6 & 1.6 & 9 & & \\
\hline 6 & 33 & 0 & 0 & 0 & 33 & 8.6 & 100 & & \\
\hline \multicolumn{10}{|c|}{ Education level } \\
\hline Primary & 34 & 31 & 8.1 & 91 & 3 & 0.8 & 9 & \multirow{3}{*}{9.727} & \multirow{3}{*}{0.008} \\
\hline Secondary & 93 & 90 & 23.4 & 97 & 3 & 0.8 & 3 & & \\
\hline University & 257 & 218 & 56.8 & 85 & 39 & 10.2 & 15 & & \\
\hline \multicolumn{10}{|c|}{ Income, USD } \\
\hline$<500$ & 28 & 22 & 5.7 & 79 & 6 & 1.6 & 21 & \multirow{4}{*}{18.974} & \multirow{4}{*}{$<0.001$} \\
\hline $500-1000$ & 101 & 98 & 25.5 & 97 & 3 & 0.8 & 3 & & \\
\hline $1000-1500$ & 155 & 140 & 36.5 & 90 & 15 & 3.9 & 10 & & \\
\hline$>1500$ & 100 & 79 & 20.6 & 79 & 21 & 5.5 & 21 & & \\
\hline
\end{tabular}

a: percent of total respondents, b: percent of related factors

In our experiment, no relationship was found between the knowledge of whether or not to use hormones in the feeding of broilers and the gender and age knowledge of the consumers. As the education of consumers increases, the belief that hormone is used in the diet of broiler chickens decreases, and it is believed that hormones are used as their education decreases. On the other hand, as the number of family members increases, belief about hormone use decreases. Consumers with an income between 500 USD and 1500 USD are more likely to believe that hormones are used in the diet of broilers (Table 1) despite the fact that added hormones are banned in production. Although the use of hormones and antibiotics as growth factors in poultry feed is prohibited, it is claimed that broiler meat is not safe food by claiming that they are used as additives. Demir and Aydin (2018) reported that $70 \%$ of consumers perceive chicken meat as risky in line with the news about the use of hormones and antibiotics. Yang (2017) determined in his study, he conducted in
Oklahoma that hormone use negatively affected consumer preferences. It was reported that as the education and income status of the consumers increased, the rate of those who thought that chicken meat was risky in terms of hormones and antibiotics and the rate of those who reduced their consumption in line with the news (Demir and Aydin, 2018). All news and articles written in two different national newspapers were analyzed to describe and compare the use of antibiotics and hormones in poultry production between 1994 and 2014 in the United States. It has been determined that the number of texts written about the awareness and concerns of consumers about the use of antibiotics and/or hormones in poultry production, the regulation of the use of antibiotics in poultry production, their intended use and transparency have increased (Edgar et al., 2017).

Lusk and Briggeman (2009) examined the effects of taste, price, safety, nutrition, tradition, origin, justice, naturalness, appearance and environmental characteristics 
on consumer attitudes. He determined that the most important food characteristics for consumers are food safety, price and taste. Consumers' reactions to food safety risks are affected by demographic characteristics such as gender, age, (Kirk et al., 2002), income (Kılıç et al., 2020), and education (Kirk et al., 2002; Kılıç et al., 2020). Kubberød et al. (2002) showed that aversion to red meat varieties was more common in women than men.

Growth hormone or somatotropin hormone stimulates growth, cell production and regeneration in humans and animals. These products, which have a very short half-life, are rapidly excreted in the feces and urine after being metabolized and broken down in the animal's organs; consequently, no beta-agonist is stored in animal tissues. In order for growth hormone to be successful, chickens had to be injected every day and several times a day. However, such an application is not possible in terms of logistics. Also, only 2 to $5 \%$ of the estrogen taken into the body can remain active form, it is metabolized in the intestinal mucosa and $90 \%$ of it is inactivated in the liver. All these hormones act as growth promoters in animals to provide greater live weight and feed utilization. It is estimated that more than 90 percent of beef cattle in the USA are used hormones to improve weight gain (USDA, 2013). While the use of hormones in poultry and pig production is banned in the EU and the US (USDA, 2017), other growth promoters (beta-agonists) are also used in $60 \%$ to $80 \%$ of beef cattle in the USA (PSE, 2016). Although the use of hormones in poultry production is illegal, consumers disagree with the view that hormones are never given to poultry (Donoghue, 2003). On the other hand, there are studies (Donoghue, 2003; Verbeke and Viaene, 1999) that support the knowledge that antibiotic levels are safe and hormones are not used in traditionally produced poultry. It has been reported that consumers are willing to pay more because natural or organic chicken meats are healthier and contain less pesticides, hormones and antibiotics (Van Loo et al., 2010; Sismanoglou and Tzimitra-Kalogianni, 2011). The rates of hormone use perceived by the consumer are 99\% different from the actual hormone use rates. Unfortunately, consumers underestimate the use of hormones in beef and overestimate the use of hormones in pigs and poultry (Yang et al., 2017). This may make consumers think that hormones are used in meat production in general. Thus, consumer perception of the use of hormones in different types of livestock does not match the facts. Indeed, consumers believe that beef is produced without hormones, but hormones are used in the production of pork and poultry, although hormones are not used in the production (Yang et al., 2017). Since consumer beliefs affect preference, it is recommended to determine consumer beliefs in consumer preference research (Verbeke et al., 2005; Verbeke et al., 2013; Lusk, Schroeder and Tonsor, 2014). Meat demand is also affected by the misconceptions of consumers about the use of hormones in different livestock. On the other hand, labeled products can lead consumers to believe that they are different or healthier than products without labels. The hormone-free label is influenced by the consumer's perception of hormone use and demographic characteristics (Yang et al., 2017). Misconceptions of consumers regarding the use of hormones in the meat industry affect their food choices. Considering that many consumers do not directly participate in food production, it can be said that they make food choices with false beliefs about production claims (Yang et al., 2017).

It was also aimed to determine how the use of therapeutic antibiotics in the feeding of broiler chickens affects the purchasing decision of the consumers in this study. To the surveyors, how does the use of therapeutic antibiotics in the feeding of broilers affect your purchasing decision? The question has been asked (Table 2). 11.2\% of the consumers stated that it would not affect their purchasing decisions at all, 39.1\% would affect it little, $47.4 \%$ would affect it a lot, and $2.3 \%$ would buy more. The results of a survey show that the acceptability of antibiotic use was influenced by the participants having objective information about antibiotic use and antibiotic resistance (Gulab, 2018). Gulab, (2018) reported that attitudes towards animal welfare and demographic characteristics such as age, gender and race affect the acceptance conditions of antibiotic use in animals. In our study, it was determined that the knowledge of using antibiotics in feeding broilers according to age, educational status and the number of family members creates a different response on purchase. It has been reported that consumption of chicken meat products does not differ between age groups from the age of 25 to the oldest population and that males consume more chicken than females (Knierim, 2006).

The effect of therapeutic antibiotic use on meat consumption in broilers was not found to be related to the education and income levels of consumers, but differences were found in terms of gender, age and number of family members. It has been found that the knowledge of antibiotics used for therapeutic purposes affects the purchasing decision of male consumers more positively, and consumers between the ages of 18 and 45 are more positively affected by this information. It is understood that as the number of family members increases, the purchasing decision was affected more (Table 2). Beyond all that, it is concluded that the public's knowledge has an important connection to their attitudes and consumption of chicken meat (Erian and Phillips, 2017).

Antibiotics are used in animal nutrition for two main reasons. One of them is its use as a growth factor in the form of feed additives. The use of antibiotics in animal feeding in this form was banned in EU countries in 2016. The second is the use of antibiotics to treat diseases. In this form, antibiotic use is withdrawn 7 days before slaughter and antibiotic residue is not allowed in meat. In the United States, approximately 14,788 tons of antimicrobials were used in animals for both therapeutic and sub-therapeutic use (FDA 2015). MacDonald and Wang (2011) reported that $42 \%$ of broiler producers do not use sub-therapeutic antibiotics in the diet or water. However, antibiotic use and antibiotic resistance in animal production continue to be discussed today (Kennedy, 2013). Concerns about increased antimicrobial resistance led to the banning of antimicrobials as growth promoters in European countries. Following this, in the United States, the FDA banned the use of antibiotics to support weight gain in animal (FDA 2016). 
Table 2. The effects of the use of therapeutic antibiotics in the diet of broilers on the purchasing decision of consumers and its change according to the socio-economic structure

\begin{tabular}{|c|c|c|c|c|c|c|c|c|c|c|c|c|c|c|c|}
\hline & \multirow{2}{*}{$\mathrm{N}$} & \multicolumn{3}{|c|}{ It doesn't effect } & \multicolumn{3}{|c|}{ Effect a little } & \multicolumn{3}{|c|}{ Effect a great deal } & \multicolumn{3}{|c|}{ I buy more } & \multirow[b]{2}{*}{$\chi^{2}$} & \multirow[b]{2}{*}{$\mathrm{P}$} \\
\hline & & $\mathrm{N}$ & $\%^{\mathrm{a}}$ & $\%^{\mathrm{b}}$ & $\mathrm{n}$ & $\%^{\mathrm{a}}$ & $\%^{\mathrm{b}}$ & $\mathrm{n}$ & $\%^{\mathrm{a}}$ & $\%^{\mathrm{b}}$ & $\mathrm{n}$ & $\%^{\mathrm{a}}$ & $\%^{\mathrm{b}}$ & & \\
\hline \multicolumn{16}{|c|}{ Gender } \\
\hline Male & 186 & 11 & 2.9 & 6 & 72 & 18.8 & 39 & 97 & 25.3 & 52 & 6 & 1.6 & 3 & \multirow{2}{*}{11.924} & \multirow{2}{*}{0.008} \\
\hline Female & 198 & 32 & 8.3 & 16 & 78 & 20.3 & 39 & 85 & 22.1 & 43 & 3 & 0.8 & 2 & & \\
\hline \multicolumn{16}{|c|}{ Age } \\
\hline $18-45$ & 198 & 15 & 3.9 & 8 & 72 & 18.8 & 36 & 108 & 28.1 & 55 & 3 & 0.8 & 2 & \multirow{3}{*}{52.246} & \multirow{3}{*}{0.001} \\
\hline $46-60$ & 131 & 8 & 2.1 & 6 & 56 & 14.6 & 43 & 64 & 16.7 & 49 & 3 & 0.8 & 2 & & \\
\hline $61>$ & 55 & 20 & 5.2 & 36 & 22 & 5.7 & 40 & 10 & 2.6 & 18 & 3 & 0.8 & 5 & & \\
\hline \multicolumn{16}{|c|}{ Number of family member } \\
\hline 2 & 45 & 7 & 1.8 & 15 & 13 & 3.4 & 29 & 22 & 5.7 & 49 & 3 & 0.8 & 7 & \multirow{5}{*}{31.880} & \multirow{5}{*}{0.001} \\
\hline 3 & 48 & 8 & 2.1 & 17 & 23 & 6 & 48 & 17 & 4.4 & 35 & 0 & 0 & 0 & & \\
\hline 4 & 193 & 20 & 5.2 & 10 & 66 & 17.2 & 34 & 104 & 27.1 & 54 & 3 & 0.8 & 2 & & \\
\hline 5 & 65 & 8 & 2.1 & 12 & 35 & 9.1 & 54 & 22 & 5.7 & 34 & 0 & 0 & 0 & & \\
\hline 6 & 33 & 0 & 0 & 0 & 13 & 3.4 & 39 & 17 & 4.4 & 52 & 3 & 0.8 & 9 & & \\
\hline \multicolumn{16}{|c|}{ Education level } \\
\hline Primary & 34 & 4 & 1 & 12 & 13 & 3.4 & 38 & 17 & 4.4 & 50 & 0 & 0 & 0 & \multirow{3}{*}{11.139} & \multirow{3}{*}{0.084} \\
\hline Secondary & 93 & 4 & 1 & 4 & 41 & 10.7 & 44 & 48 & 12.5 & 52 & 0 & 0 & 0 & & \\
\hline University & 257 & 35 & 9.1 & 14 & 96 & 25 & 37 & 117 & 30.5 & 46 & 9 & 2.3 & 4 & & \\
\hline \multicolumn{16}{|c|}{ Income, USD } \\
\hline$<500$ & 28 & 4 & 1 & 14 & 13 & 3.4 & 46 & 11 & 2.9 & 39 & 0 & 0 & 0 & \multirow{4}{*}{15.048} & \multirow{4}{*}{0.089} \\
\hline $500-1000$ & 101 & 7 & 1.8 & 7 & 35 & 9.1 & 35 & 53 & 13.8 & 52 & 6 & 1.6 & 6 & & \\
\hline $1000-1500$ & 155 & 16 & 4.2 & 10 & 65 & 16.9 & 42 & 71 & 18.5 & 46 & 3 & 0.8 & 2 & & \\
\hline$>1500$ & 100 & 16 & 4.2 & 16 & 37 & 9.6 & 37 & 47 & 12.2 & 47 & 0 & 0 & 0 & & \\
\hline
\end{tabular}

a: percent of total respondents, $b$ : percent of related factors

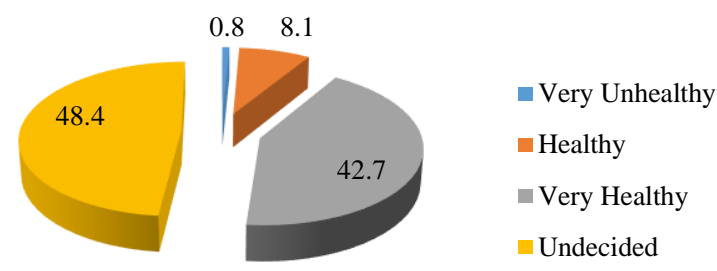

Figure 1. What do you think about the food security of chicken meats sold in markets?

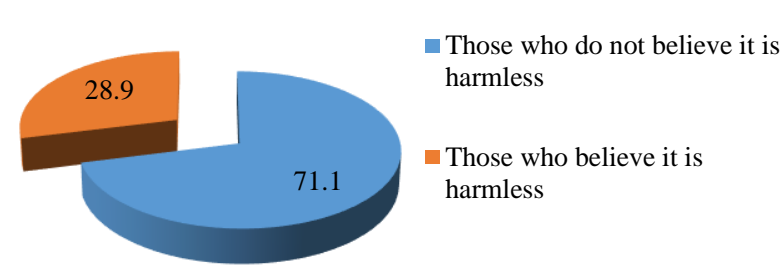

Figure 3. Do you think that feed additives are natural or harmless to human health?

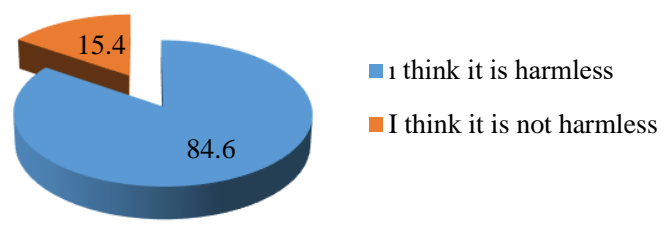

Figure 2. Do you think that the use of antibiotics for therapeutic purposes in broiler chickens is harmful to human health?

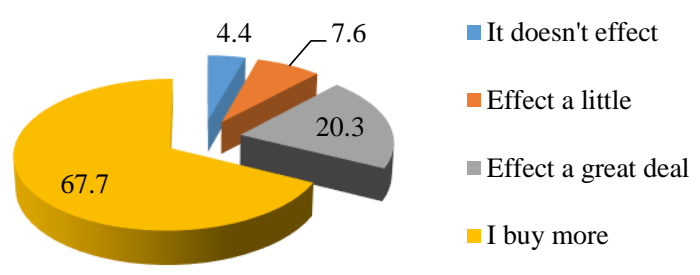

Figure 4. How does knowing that feed additives are natural or harmless will affect your chicken meat consumption? 
Do you think chicken meats on the market are safe? The question was asked to the pollsters. $42.7 \%$ of the consumers who participated in the survey stated that chicken meats sold in the market were very unhealthy, $48.4 \%$ were unstable, $8.1 \%$ were healthy and $0.8 \%$ were very healthy (Figure 1). Male consumers who participated in the survey with the knowledge of whether the chicken purchased is safe or not, have less confidence in chicken meat than female consumers. Young consumers also have less confidence in chicken meat than middle-aged and elderly consumers. As the education level of consumers increases, the trust in chicken meat also increases. As the income level of consumers increases, the trust in chicken meat decreases.

Do you think that the use of antibiotics for therapeutic purposes in the feeding of broilers is harmful to human health? The question has been asked. While $15.4 \%$ of the consumers participating in the survey stated that they think it is not harmful, $84.6 \%$ of them stated that they think it is harmful to human health (Figure 2). No difference was found between the information on whether the antibiotics used for therapeutic purposes in the feeding of the purchased chicken are harmful or not and the gender and income status of the consumers who participated in the survey. As the age and educational status of consumer's increase, the rate of those who think that the use of antibiotics for therapeutic purposes is harmful.

Do you believe that the feed additives are natural or harmless to human health? The question was asked to the pollsters. While $71.1 \%$ of the consumers participated the survey believe that feed additives are not natural or harmless, $28.9 \%$ of consumers believe that they are natural or harmless (Figure 3). If you know that the feed additives in diets are natural or harmless, how does this information affect your decision to buy broiler meat? They stated that it would not affect $4.4 \%$ of the consumers participating in the survey, $20.3 \%$ stated that it would affect it little, $67.7 \%$ stated that it would affect it very much, and $7.6 \%$ stated that they would buy more (Figure, 4 ). The fact that the feed additives used in the feeding of the purchased chicken are natural or harmless will affect the consumption of chicken meat more than the male consumers. As the age and education level of the consumer increases, the consumers stated that even if harmless feed additives are used in the diet of broilers, they will not change their consumption.

In this study, what do you think is the most important factor for broiler chickens to gain a live weight of 2.5-3.0 $\mathrm{kg}$ in a short time (42 days)? The question is directed to consumers (Table 3 ). Only $14.1 \%$ of consumers who participated in the survey stated that the most important factors for the broiler chickens to gain rapid live weight are the development of animals by scientific methods (breeding), feeding with balanced diets by all the nutrients and sheltering in suitable environments. However, 15.4\% of consumers stated that they grew rapidly due to the feed additives added to the diets, while the vast majority of $70.6 \%$ stated that animals grew rapidly due to antibiotics and hormones. There was no significant difference in terms of the sexes of consumers regarding the rapid gain of live weight of broiler chickens. However, statistical differences were determined in terms of age, number of family members, education and income status. Accordingly, young consumers and consumers with higher educational status and income have stated that the most important factor in broiler chickens gaining high weight in a short time is due to the scientific methods.

Table 3. Socio-demographic characteristics of the questionaries on the effect of the chicken purchased on $2.5-3.0 \mathrm{~kg}$ live weight gain knowledge in a short time

\begin{tabular}{|c|c|c|c|c|c|c|c|c|c|c|c|c|}
\hline & \multirow[t]{2}{*}{$\mathrm{N}$} & \multicolumn{3}{|c|}{$\begin{array}{l}\text { Used scientific } \\
\text { methods }\end{array}$} & \multicolumn{3}{|c|}{$\begin{array}{l}\text { Feed additives } \\
\text { (others) }\end{array}$} & \multicolumn{3}{|c|}{$\begin{array}{c}\text { Antibiotics and } \\
\text { hormones }\end{array}$} & \multirow[b]{2}{*}{$\chi^{2}$} & \multirow[b]{2}{*}{$\mathrm{P}$} \\
\hline & & $\mathrm{n}$ & $\%^{\mathrm{a}}$ & $\%^{\mathrm{b}}$ & $\mathrm{n}$ & $\%^{\mathrm{a}}$ & $\%^{\mathrm{b}}$ & $\mathrm{n}$ & $\%^{a}$ & $\%^{\mathrm{b}}$ & & \\
\hline \multicolumn{13}{|c|}{ Gender } \\
\hline Male & 186 & 25 & 6.5 & 13 & 23 & 6 & 12 & 138 & 35.9 & 74 & \multirow{2}{*}{2.881} & \multirow{2}{*}{0.237} \\
\hline Female & 198 & 29 & 7.6 & 15 & 36 & 9.4 & 18 & 133 & 34.6 & 67 & & \\
\hline \multicolumn{13}{|c|}{ Age } \\
\hline $18-45$ & 198 & 36 & 9.4 & 18 & 37 & 9.6 & 19 & 125 & 32.6 & 63 & & \\
\hline $46-60$ & 131 & 18 & 4.7 & 14 & 16 & 4.2 & 12 & 97 & 25.3 & 74 & 17.563 & 0.002 \\
\hline $61>$ & 55 & 0 & 0 & 0 & 6 & 1.6 & 11 & 49 & 12.8 & 89 & & \\
\hline \multicolumn{13}{|c|}{ Family size } \\
\hline 2 & 45 & 4 & 1 & 9 & 7 & 1.8 & 16 & 34 & 8.9 & 76 & \multirow{5}{*}{33.838} & \multirow{5}{*}{$<0.001$} \\
\hline 3 & 48 & 3 & 0.8 & 6 & 13 & 3.4 & 27 & 32 & 8.3 & 67 & & \\
\hline 4 & 193 & 41 & 10.7 & 21 & 15 & 3.9 & 8 & 137 & 35.7 & 71 & & \\
\hline 5 & 65 & 6 & 1.6 & 9 & 17 & 4.4 & 26 & 42 & 10.9 & 65 & & \\
\hline 6 or more & 33 & 0 & 0 & 0 & 7 & 1.8 & 21 & 26 & 6.8 & 79 & & \\
\hline \multicolumn{13}{|c|}{ Education level } \\
\hline Primary & 34 & 6 & 1.6 & 18 & 0 & 0 & 0 & 28 & 7.3 & 82 & \multirow{3}{*}{18.569} & \multirow{3}{*}{0.001} \\
\hline Secondary & 93 & 3 & 0.8 & 3 & 16 & 4.2 & 17 & 74 & 19.3 & 80 & & \\
\hline University & 257 & 45 & 11.7 & 18 & 43 & 11.2 & 17 & 169 & 44 & 66 & & \\
\hline \multicolumn{13}{|c|}{ Income, USD } \\
\hline$<500$ & 28 & 6 & 1.6 & 21 & 0 & 0 & 0 & 22 & 5.7 & 79 & \multirow{4}{*}{37.724} & \multirow{4}{*}{$<0.001$} \\
\hline $500-1000$ & 101 & 6 & 1.6 & 6 & 16 & 4.2 & 16 & 79 & 20.6 & 78 & & \\
\hline $1000-1500$ & 155 & 22 & 5.7 & 14 & 40 & 10.4 & 26 & 93 & 24.2 & 60 & & \\
\hline$>1500$ & 100 & 20 & 5.2 & 20 & 3 & 0.8 & 3 & 77 & 20.1 & 77 & & \\
\hline
\end{tabular}

a: percent of total respondents, b: percent of related factors 
As, the age of the consumers increased, the rate of those who believed that the effects of antibiotics and hormones were important in rapid growth of broilers increased. As, the education level of consumers increases, the knowledge about the effect of scientific methods and feed additives increases, and the rate of those who believe that hormones and antibiotics are effective decreases (Table 3 ).

In recent years, consumers have been closely concerned with the price and nutritional value of poultry products, as well as product quality such as hygiene, food safety, color, aroma and flavor. In addition to the genetic characteristics and reliability of animals and feeds, it is questioned whether substances harmful to animal and human health are used (Mesias et al., 2005). The majority of consumers attributed the high live weight gain of broilers to the use of antibiotics, hormones and feed additives as well as the use of GMO feeds (Karasu and Ozturk, 2020). Van Loo et al (2010) reported that when asked whether the use of antibiotics as growth promoters is acceptable, the vast majority $(62.4 \%)$ of the pollsters strongly opposed it, while a significant portion $(30.2 \%)$ declared neither support nor opposition.

The condition of the meat to be produced, its price, and even cultural and social factors can significantly influence purchasing decisions. In conditioning consumer behavior, it is also necessary to determine how relevant certain information is, such as the origin and diet of the animal, how it was bred, its age, veterinary practices and slaughter (Mesias et al., 2005). Stuart et al. (2015) suggested that publications that reflect the reality of the use of antibiotics and hormones in poultry should be made and rational marketing strategies should be developed to combat misinforming campaigns on agriculture. Thus, consumer understanding of the health of poultry can be improved. Our research results show that the majority of consumers do not have enough information about feedstuffs, feeding and contents of diets used in broiler nutrition. The majority of consumers reported that they thought hormone and anitibiotic were used in broiler chickens. They stated that if they know that hormones and antibiotics are not used in broiler nutrition, they will affect the amount of broiler meat purchase positively.

\section{Conclusions}

These findings obtained in our study show that false perception, which are common throughout the world and do not match the facts, continues to increase. This finding revealed that the effects of unfounded rhetoric and speculative news damaging the sector on consumers are quite large. According to this result, it is necessary to increase the knowledge level of consumers and to allow them to make conscious choices. It is important for the future of the sector that the stakeholders of the sector present the legal legislation that antibiotics and hormones are not used in animal feeding.

\section{Acknowlodgements}

We thank Ondokuz Mayis University for providing financial support to our research project (PYO.ZRT.1904.17.005). This article is summarized from Kerem Karasu's MSc thesis conducted under the supervision of Ergin Ozturk.

\section{References}

Bekar E 2013. Consumer attitudes towards food safety. Journal of Agricultural Sciences of Yuzuncuy1l University 23(2): 90-101.

Bryant C, Szejda K, Parekh N, Deshpande V and Tse B. 2019. A Survey of consumer perceptions of plant-based and clean meat in the USA, India, and China. Frontiers in Sustainable Food Systems, 3: 11. doi: 10.3389/fsufs.2019.00011

Caro D, Davis SJ, Bastianoni S and Caldeira K. 2017. Greenhouse gas emissions due to meat production in the last fifty years, January 2017, In book: Quantification of Climate Variability, Adaptation and Mitigation for Agricultural Sustainability (pp.27-37) doi: 10.1007/978-3-319-32059-5_2.

Collins M. 1986. Consumer market research handbook. Sampling editör: R. Worcester, vd. Eisevier Science Publishing Company Inc. London.

Demir AP and Aydin E. 2018. Negative on hormone and antibiotic use the effect of news on consumers' consumption habits of chicken meat (Kars province example). Journal of Mehmet Akif Ersoy Veterinary Faculty 3(1): 55-63.

Dokuzlu S, Barış O, Secer C and Güldaş M. 2013. Chicken meat consumption habits and brand preferences in Turkey. Journal of Uludağ University Faculty of Agriculture 27(2): 83-92.

Donoghue DJ. 2003. Antibiotic residues in poultry tissues and eggs: human health concerns? Poultry Science 82(4): 618621. doi:10.1093/ps/82.4.618.

Edgar LD, Johnson DM and Estes S. 2017. Poultry production messaging in two national-circulation newspapers. Journal of Applied Communications 6-19.

Erian I and Phillips CJ. 2017. Public understanding and attitudes towards meat chicken production and relations to consumption. Animals 7(3): 20.

FAO. 2017. Meat and meat product. Food and Agriculture Organization of the United Nations, Rome.

Fiala N. 2008. Meeting the demand: An estimation of potential future greenhouse gas emissions from meat production. Ecological Economics, 67(3), 412-419. https://doi.org/ 10.1016/j.ecolecon.2007.12.021

Food And Drug Administration (FDA). 2015. "Steroid Hormone Implants Used for Growth in Food-Producing Animals." Oct.20, 2015.

Food And Drug Administration (FDA). 2016. Reminds reatils establishements of upcomingchanges to the use of antibiotics in food animals. https://www.fda.gov/AnimalVeterinary/ NewsEvents/CVMUpdates/ucm507355.ht Accessed Agust 1, 2020.

Gulab S. 2018. Understanding consumer attitudes towards antimicrobial risk reducing practices, (Masters Thesis), pp 88. The University of Nebraska, Lincoln, Nebraska. http://digitalcommons.unl.edu/agecondiss/51

İnci H, Karakaya E, Şengül T and Söğ̈̈t B. 2014. The structure of poultry meat consumption in Bingöl province. Turkish Journal of Agricultural and Natural Sciences 1(1): 17-24.

Jeong SH, Kang D, Lim MV, Kang CS and Sung HJ. 2010. Risk assessment of growth hormones and antimicrobial residues in meat. Toxicology Research 26(4): 301-313. doi: 10.5487/ TR.2010.26.4.301.

Karadavut U and Taşkın A. 2014. Determination of factors affecting poultry meat consumption in Kirşehir province, Tekirdağ Namık Kemal Üniversitesi Ziraat Fakültesi Dergisi 11(1): 37-43.

Karasu K and Ozturk E. 2020. The effects of genetically modified feeds on consumers' preferences in buying broiler meat. Austin Journal of Nutrition \& Metabolism 7(4): 1087.

Kennedy D. 2013. Time to deal with antibiotics. Science 342:777.

Kılıç O, Boz İ, Eryılmaz A.G. 2020. Determination of consumers' behaviors in food purchasing, conservation, consumption, and food safety. Journal of Management and Economics Research (Yönetim ve Ekonomi Araştırmaları Dergisi) 18(2): 29-40. doi: http://dx.doi.org/10.11611/yead.673537 
Kirk SF, Greenwood D, Cade JE and Pearman AD. 2002. Public perception of a range of potential food risks in the United Kingdom. Appetite 38(3): 189-197.

Knierim U. 2006. Animal welfare aspects of outdoor runs for laying hens: a review. NJAS - Wageningen Journal of Life Sciences 54 (2):133-145.

Kubberød E, Uelan O, Rødbotten M, Westad F and Risvisk E. 2002. Gender specific preferences and attitudes towards meat. Food Quality and Preference 13(5): 285-294.

Lusk JL and Briggeman B. 2009. Food values. American Journal of Agricultural Economics 91(1): 184-196.

Lusk JL, Schroeder TC and Tonsor GT. 2014. "Distinguishing beliefs from preferences in food choice.” European Review of Agricultural Economics 41(4): 627-655.

MacDonald JM and Wang SL. 2011. Foregoing sub-therapeutic antibiotics: the impact on broiler grow-out operations. Applied Economic Perspectives and Policy 33(1): 79-98. doi: 10.1093/aepp/ppq030.

Mayfield LE, Bennett RM, Tranter RB and Woolridge MJ. 2007. Consumption of welfare-friendly food products in Great Britain, Italy and Sweden, an how it may be influenced by consumer attitudes to, and behaviour towards, animal welfare attributes. International Journal of Sociology of Food and Agriculture 15(3): 59-73.

Mesías FJ, Escribano M, Rodríguez de Ledesma A and Pulido F. 2005. Consumers' preferences for beef in the Spanish region of Extremadura: A study using conjoint analysis. Journal of the Science of Food and Agriculture 85: 2487-2494.

Naspetti S, Alberti F and Solfanelli F. 2015, "Quality function deployment in the organic animal food sector: application to poultry meat". Italian Journal of Animal Science 14: 544-550.

Ozturk E. 2017. Performance of broilers fed with different levels of sunflower meal supplemented with or without enzymes. Indian Journal of Animal Research 51(3): 495-500. doi: 10.18805/ijar.v0i0f.3799.

Ozturk E, Ocak N, Turan A, Erener G, Altop A and Cankaya S. 2012. Performance, carcass, gastrointestinal tract and meat quality traits, and selected blood parameters of broilers fed diets supplemented with humic substances. Journal of the Science of Food and Agriculture 92: 59-65. doi:10.1002/ jsfa.4541.

PSE. 2016. Penn State Extension, "Use of beta-agonists in cattle feed" 2016.

Şengül T and Zeybek S. 2020. A research on chicken meat perceptions of consumers living in the Diyarbakır city center and the factors affecting these perceptions. Turkish Journal of Agricultural and Natural Sciences 2: 433-440.

Sismanoglou A and Tzimitra-Kalogianni I. 2011. Consumer perception of poultry meat in Greece. Worlds' Poultry Science Journal 67: 269-276.
Steinfeld H, Gerber P, Wassenaar T, Castel V, Rosales M and de Hann C. 2006. Livestock's long shadow, environmental issues and options. Food and Agriculture Organization of the United Nations.

Stuart E, Edgar LD and Johnson DM. 2015 "Consumer perceptions of poultry production: A focus on Arkansas". Journal of Applied Communications 99(4):34-48. https://dx.doi.org/10.4148/1051-0834.1057

Topçu Y, Uzundumlu SA and Baran D. 2015. Analysis of factors affecting consumers' attitudes and behaviors regarding chicken meat consumption. Turkish Agriculture-Food Science and Technology Journal 3(5): 242-247.

USDA. 2013.United States Department of Agriculture. "The use of growth-promoting implants in U.S. feedlots." Animal and Plant Health Inspection Service. August 5, 2020.

USDA. 2017. United States Department of Agriculture "Meat and poultry labeling terms" [Accessed August 10, 2020]. Available from https://www.fsis.usda.gov/wps/portal/fsis/ topics/food-safety-education/get-answers/food-safetyfactsheets/food-labeling/meat-and-poultry-labelingterms/meat-and-poultry-labeling-terms.

Van Loo E, Caputo V, Nayga M, Rodolfo J, Meullenet JF, Crandall PG and Ricke SC. 2010. Effect of organic poultry purchase frequency on consumer attitudes toward organic poultry meat. Journal of Food Science 75(7): 384-397. doi:10.1111/j.1750-3841.2010.01775.x

Verbeke W. 2005. Agriculture and the food industry in the information age. European Review of Agricultural Economics 32: 347-368.

Verbeke W and Vackier I. 2004. Profile and effects of consumer involvement in fresh meat. Meat Science 67: 159-168.

Verbeke W, Demey V, Bosmans W and Viaene J. 2005. "Consumer versus producer expectations and motivations related to 'superior' quality meat: qualitative research findings". Journal of Food Products Marketing 11(3): 27-41.

Verbeke W, Rutsaert P, Bonne K and Vermeir I. 2013. Credence quality coordination and consumers' willingness-to-pay for certified halal labelled meat. Meat Science 95: 790-797.

Verbeke WAJ and Viaene J. 1999. Ethical challenges for livestock production: Meeting consumer concerns about meat safety and animal welfare. Journal of Agricultural and Environmental Ethics 12: 141-151.

Yang R, Raper KC and Lusk JL. 2017. The impact of hormone use perception on consumer meat preference. Southern Agricultural Economics Association (SAEA) Annual Meeting Conference Paper Presentation, February 4-7, 2017, Alabama (No. 1377-2016-109843) doi: 10.22004/ ag.econ.252772, http://purl.umn.edu/252772. 